University of Nebraska - Lincoln

DigitalCommons@University of Nebraska - Lincoln

Publications, Agencies and Staff of the U.S.

Department of Commerce

U.S. Department of Commerce

2012

Changes in atmospheric circulation patterns associated with high and low rainfall regimes in the Hawaiian Islands region on multiple time scales

Henry F. Diaz

NOAA/CIRES, henry.f.diaz@noaa.gov

Thomas W. Giambelluca

University of Hawaii at Manoa

Follow this and additional works at: https://digitalcommons.unl.edu/usdeptcommercepub

Part of the Environmental Sciences Commons

Diaz, Henry F. and Giambelluca, Thomas W., "Changes in atmospheric circulation patterns associated with high and low rainfall regimes in the Hawaiian Islands region on multiple time scales" (2012). Publications, Agencies and Staff of the U.S. Department of Commerce. 379.

https://digitalcommons.unl.edu/usdeptcommercepub/379

This Article is brought to you for free and open access by the U.S. Department of Commerce at DigitalCommons@University of Nebraska - Lincoln. It has been accepted for inclusion in Publications, Agencies and Staff of the U.S. Department of Commerce by an authorized administrator of DigitalCommons@University of Nebraska - Lincoln. 


\title{
Changes in atmospheric circulation patterns associated with high and low rainfall regimes in the Hawaiian Islands region on multiple time scales
}

\author{
Henry F. Diaz ${ }^{\text {a,* }}$, Thomas W. Giambelluca ${ }^{\text {b }}$ \\ a NOAA/CIRES, University of Colorado, Boulder, CO, USA \\ b Department of Geography, University of Hawai'i Mānoa, Honolulu, HI, USA
}

\section{A R T I C L E I N F O}

Article history:

Received 13 February 2012

Accepted 29 August 2012

Available online 5 September 2012

\section{Keywords:}

Hawai'i rainfall

Seasonal to multi-decadal variability

Characteristic patterns of anomalous large-

scale circulation

Climatic changes

\begin{abstract}
A B S T R A C T
We examine a suite of climate variables in the North Pacific associated with different temporal scales of dry and wet episodes in the Hawaiian Islands. The goal is to ascertain whether varying the length in the occurrence of such events from seasonal to multi-decadal results from different ocean-atmosphere circulation patterns over the North Pacific region. We find that as the dryness period lengthens, the spatial scale of the anomalies widens, but the characteristics of the anomalous circulation fields exhibit elements evident at each time scale. At the longest (multi-decadal) time scales during the wet season (November-April), the major anomalous circulation features associated with above (below) average rainfall in Hawai'i are a strengthening (weakening) of the North Pacific mid-latitude westerlies associated with a strengthened (weakened) Aleutian Low system, a slight weakening (strengthening) of the northeast trade winds, with anomalous northerly (southerly) component to the south of the Islands, together with diminished (enhanced) precipitation across most of the tropical North Pacific. During the summer dry season (May-October) a characteristic pattern that is evident at different time scales during drier than normal periods is a strengthening of the trade winds to the south of the Islands, with sinking motion extending from the latitude of Hawai'i eastward to Central America. Conversely, wet summers are associated with generally weaker trades to the south with a tendency for anomalous southwesterly component. We also consider possible changes in the relationship of Hawaiian rainfall to changes in the Pacific-Decadal Oscillation (PDO) but conclude that the record is too short to establish the significance of any changes in an overall negative correlation.
\end{abstract}

(c) 2012 Elsevier B.V. All rights reserved.

\section{Introduction}

Although the Hawaiian Islands contain some of the rainiest sites on Earth, periods of sustained dryness do affect the Islands periodically (Giambelluca et al., 1991). Some previous studies that have examined rainfall variability in Hawai'i include those by Lyons (1982) and Chu (1989) for seasonal means, and those by Chu and Chen (2005), Timm and Diaz (2009), Chu et al. (2010), and Elison Timm et al. (2011) for interannual to decadal and longer timescales. Secular trends are also evident in many other regional climatic series (Giambelluca et al., 2008; Diaz et al., 2011).

Rainfall in Hawai'i is characterized by a wet winter half-year and a dry (summer) season. Four different mechanisms for rainfall production have been identified in previous meteorological studies (Chu et al., 1993; Schroeder, 1993). Several primary mechanisms have been found to modulate rainfall in the Hawaiian Islands (Lyons, 1982), but we will here focus mainly on changes in the strength trade wind-induced rainfall along the windward-facing sides of the

\footnotetext{
* Corresponding author.

E-mail address: henry.f.diaz@noaa.gov (H.F. Diaz).
}

mountain slopes, and changes in the influence of westerly disturbances that affect the Islands mostly during the winter half-year.

We explore the following question: Is there a difference in the large-scale circulation features in the North Pacific sector associated with drought in Hawai'i when they are examined at annual, decadal, and multi-decadal time scales? We also examine possible changes in the strength of the association between Hawai'i rainfall and the Pacific Decadal Oscillation, and include some discussion about the possible effects of global warming on Hawai'i's rainfall regime.

The extreme spatial diversity of rainfall in Hawai'i (Giambelluca et al., 2012) calls attention to the dominant controls on rainfall, and sheds light on the circumstances that produce drought. Orographic lifting of trade winds provides persistent rainfall along east facing mountain slopes, reaching near world-record mean annual totals at favored locations. Topographic blocking and channeling of winds and thermally-driven local circulation near coasts and along slopes alters the trade-wind pattern, most notably in the Kona region of Hawai'i Island, where westerly surface flow produces a summer-maximum rainfall regime unique in the islands. Lastly, Hadley cell subsidence maintains a temperature inversion, known as the trade wind inversion (TWI), found $80-90 \%$ of the time at an average elevation of about $2200 \mathrm{~m}$ (Cao et al., 2007), which effectively caps lifting and produces 


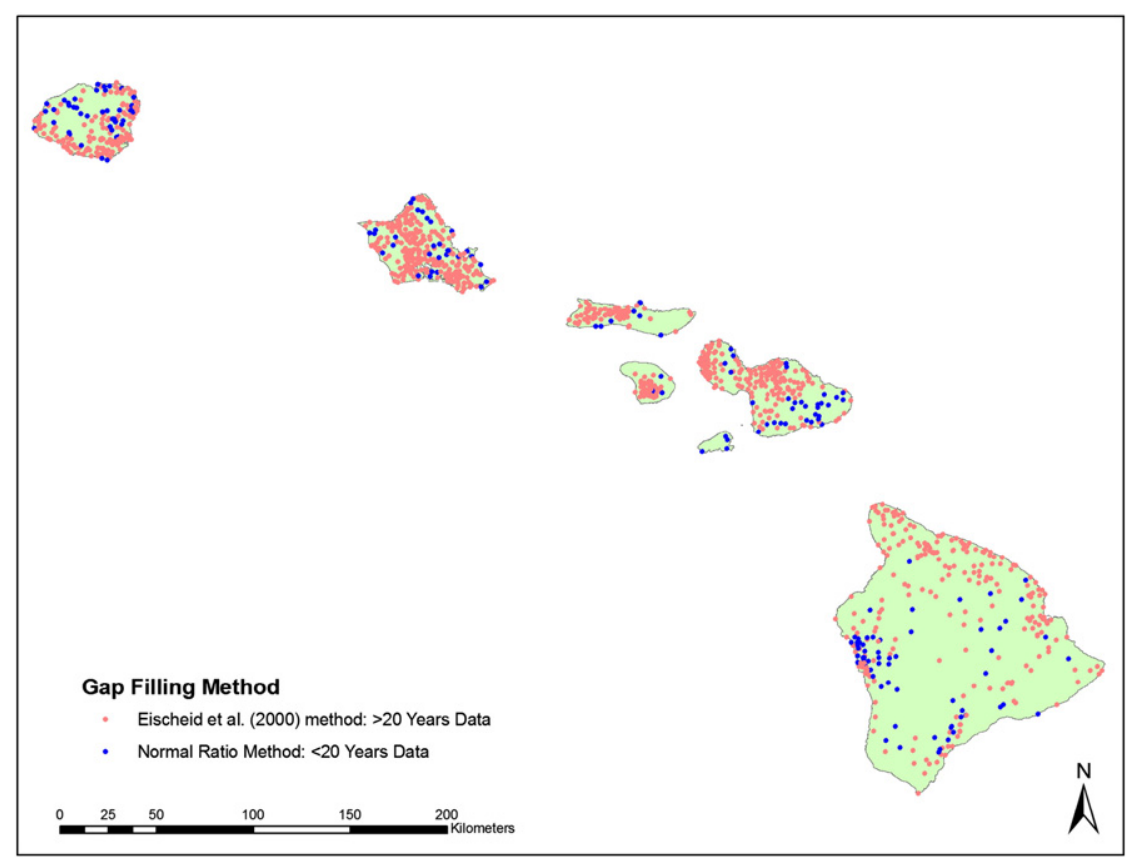

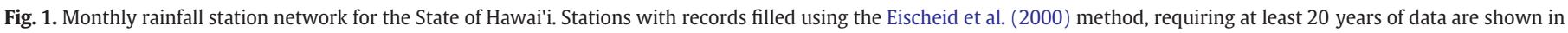
pink. Stations with less than 20 years of record filled with the normal ratio method are shown in blue (see Frazier, 2012).

arid zones at the tops of Hawai'i's highest mountains. Leeward coastal areas and the high summits receive significant rainfall only during disturbances, mainly subtropical lows (Kona storms), upper level lows, and cold fronts, all of which occur mainly during November-April.

Hawai'i is strongly affected by the Pacific-centered coupled ocean-atmosphere modes, El Niño-Southern Oscillation (ENSO) and Pacific Decadal Oscillation (PDO). El Niño events are highly correlated with deficient winter rainfall in Hawai'i, while the positive (negative) phase of the PDO is linked with multi-decadal dry (wet) periods (Chu and Chen, 2005). Generally, drought in Hawai'i can result from an absence of the disturbances that usually interrupt subsidence and eliminate the TWI, and/or from a lengthy period without trade winds. Thus, droughts are likely to be associated with particular anomalies in North-Pacific-wide atmospheric circulation patterns. However, it is not known how these circulation anomalies might differ when assessing drought on different time scales. Rainfall changes projected for the Hawaiian Islands region associated with global warming are uncertain (Timm and Diaz, 2009; Elison Timm et al., 2011); hence an analysis of observed changes expressed over varying

Table 1

Mean monthly rainfall for Hawai'i averaged over the period 1920-2007.

\begin{tabular}{lc}
\hline Month & Mean $(\mathrm{mm})$ \\
\hline Jan & 180.3 \\
Feb & 146.6 \\
Mar & 193.8 \\
Apr & 166.6 \\
May & 123.4 \\
Jun & 88.1 \\
Jul & 118.6 \\
Aug & 128.0 \\
Sep & 110.5 \\
Oct & 132.1 \\
Nov & 171.2 \\
Dec & 174.2 \\
Annual & 1733.4 \\
\hline
\end{tabular}

time intervals could be useful for climate change detection and attribution purposes.

\section{Data and methods}

We have produced a comprehensive precipitation data set of the State of Hawai'i based on the summary of the month climate data set from the National Climatic Data Center (NCDC) in Asheville, NC, supplemented by additional station records digitized from original records available at the University of Hawai'i at Mānoa, and other small networks. The data set comprises 928 rainfall measuring stations covering the period 1920-2007 (see Fig. 1; Giambelluca et al., 2011; Frazier, 2012). Gaps in the record were filled in using optimal regression estimates for stations with $>20$ years of record (Eischeid et al., 2000). In some data sparse regions, the normal ratio method was used for gap filling, referenced to up to 4 stations with the best calendar month correlation with the target stations. The individual estimates were then averaged to fill the missing record. The Thiessen Polygon method was used to produce area-weighted averages for individual islands and the whole State (Frazier et al., 2011). Table 1 gives state mean monthly precipitation values and Table 2 compares 30 -year means from different precipitation climatologies for the State.

Table 2

Comparison of annual mean precipitation values for the main Hawaiian Islands based on different sources: the 2011 Rainfall Atlas (1978-2007; Giambelluca et al., 2011), PRISM maps (1971-2000; Daly et al., 2006), 1978-2007 areal averages derived using the Thiessen Polygon method (Frazier et al., 2011) for the major Hawaiian Islands. Values in inches as in the original data.

\begin{tabular}{llll}
\hline & $\begin{array}{l}\text { 2011 Rainfall } \\
\text { Atlas }\end{array}$ & PRISM & $\begin{array}{l}\text { Thiessen polygon } \\
\text { analysis }\end{array}$ \\
\hline Kaua'i & 84.26 & 86.74 & 79.04 \\
O'ahu & 64.10 & 67.14 & 59.35 \\
Moloka'i & 48.58 & 43.83 & 46.47 \\
Lāna'i & 22.04 & 24.22 & 20.92 \\
Maui \& Kaho'olawe & 77.36 & 74.36 & 75.64 \\
Hawai'i & 72.75 & 72.65 & 70.16 \\
\hline
\end{tabular}


Table 3

Listing of significant seasonal dry spells for Hawai'i since 1948. Percentages are relative to a 1920-2007 State average for the driest 10 (out of 60) individual seasons.

\begin{tabular}{lllll}
\hline \multicolumn{2}{l}{ November-April rainfall } & & \multicolumn{2}{l}{ May-October rainfall } \\
\cline { 5 - 5 } Year & \% of Normal & & Year & \% of Normal \\
\hline $1991-1992^{* *}$ & $47.3 \%$ & & $1975^{\Delta}$ & $56.8 \%$ \\
$1982-1983^{* *}$ & 49.1 & 1953 & 60.3 \\
$1980-1981$ & 50.6 & $1971^{\Delta}$ & 61.3 \\
$1977-1978$ & 51.3 & 1984 & 61.7 \\
$1997-1998^{* *}$ & 54.0 & 1999 & 61.8 \\
$2002-1903^{*}$ & 54.8 & 2007 & 64.8 \\
$1983-1984$ & 59.1 & $1973^{* *}$ & 66.3 \\
$2006-1907^{*}$ & 63.6 & 1949 & 66.6 \\
$1972-1973^{* *}$ & 67.0 & 1976 & 67.3 \\
$1994-1995^{*}$ & 71.2 & $2003^{*}$ & 74.6 \\
\hline
\end{tabular}

Moderate El Niño events are denoted by a *, strong El Niño events are denoted by **. The winter of 1977-1978 was associated with weak El Niño conditions. For the MayOctober season the Niño years are for $($ Year +1$)$ of the event. ${ }^{\Delta}$ Denotes a La Niña year.

Seasonal rainfall totals for each year from 1920 to 2007 were ranked to identify the driest November-April (typically the rainier season) and May-October (typically drier) seasons over varying length periods. Different atmospheric circulation indices are composited for analysis for each season based on these years. In order to explore how the climate patterns changed depending on the averaging length, we repeated the analyses using the driest and wettest consecutive 10 and 25 years in the record. For upper air data we used the NCEP Reanalysis (NRA) data set (Kistler et al., 2001) available from NOAA/ESRL at http:// www.esrl.noaa.gov/psd/psd1/ for the period 1948-2007, and for the period prior to 1948 from the historical reanalysis (HRA) data set (Compo et al., 2011) also available from the NOAA/ESRL website. We focused on three reanalysis variables as representative of circulation pattern differences in the different periods-the $1000 \mathrm{mb}$ vector wind anomaly field, the anomaly field of $700 \mathrm{mb}$ vertical velocity (omega), and the anomaly field of surface precipitation rate. The vector wind anomaly is helpful in visualizing changes in the large-scale nearsurface circulation, while the vertical motion field at $700 \mathrm{mb}$ is closely tied to thermodynamic stability in the Islands because of the trade wind inversion and derived precipitation field is useful for comparison with the station values.

\section{Analysis results}

\subsection{Shorter-length dry spells}

Table 3 lists the 10 driest 6-month winters (November-April) and 6-month summers (May-October) since 1948 for the State as a whole along with the percent of normal (with respect to the 1920-2007 period of record mean). Note that seven of the top ten winter (wet season) droughts are associated with El Niño events, four of which are characterized as strong (1972-1973, 1982-1983, 1991-1992 and 1997-1998). For these years the corresponding seasonal precipitation was two-thirds of the long-term mean or less, including two seasons with less than $50 \%$ of the mean. Fig. 2 shows composite anomalies of near surface $(1000 \mathrm{mb})$ winds, the vertical motion field at $700 \mathrm{mb}$, and surface rain rate. As one might expect, these dry intervals are associated with anomalous anticyclonic flow and weaker trades in the vicinity of the Hawaiian Islands, anomalous sinking motion in the middle troposphere and reduced rain-rate as specified in the NCEP Reanalysis data. A deeper Aleutian Low and attendant enhancement of the North Pacific westerlies north of Hawai'i is evident.

The anomalous patterns representative of dry years during the nominal "summer" dry season period (Table 3 ) are illustrated in
NCEP/NCAR Reanalysis

$1000 \mathrm{mb}$ Vector Wind $(\mathrm{m} / \mathrm{s})$ Composite Anomaly 1981-2010 climo

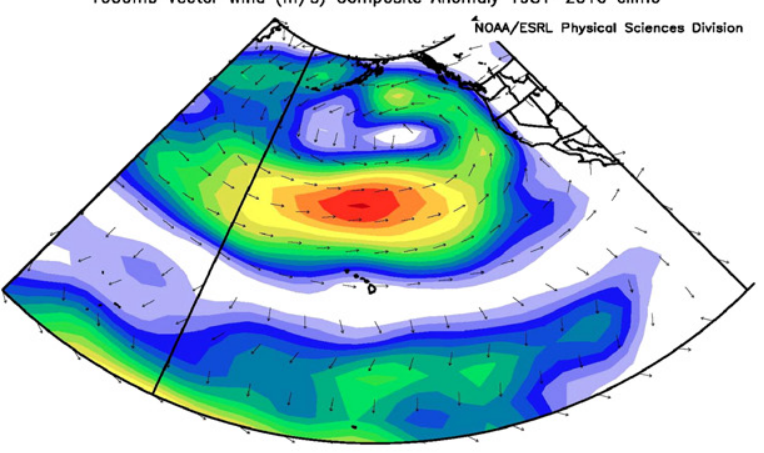

Nov to Apr: $1973,1978,1981,1983,1984,1992,1995,1998,2003,2007$
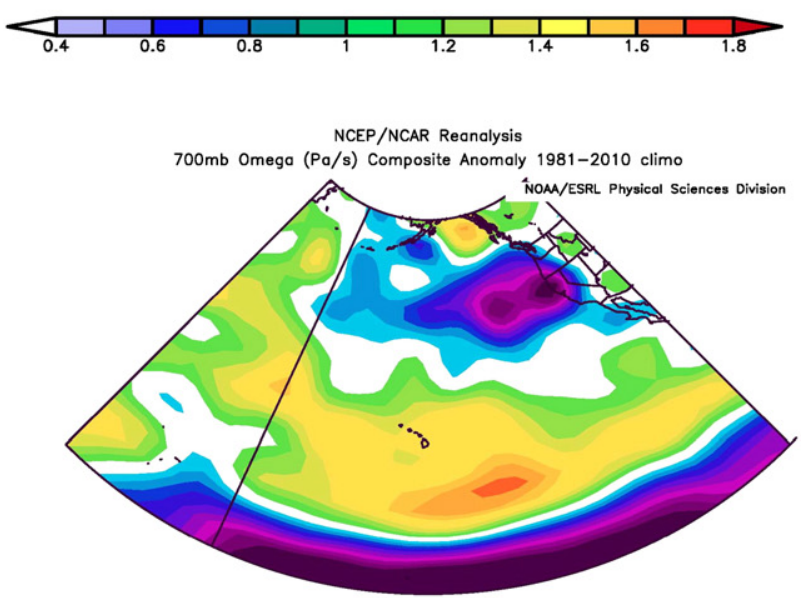

Nov to Apr: $1973,1978,1981,1983,1984,1992,1995,1998,2003,2007$
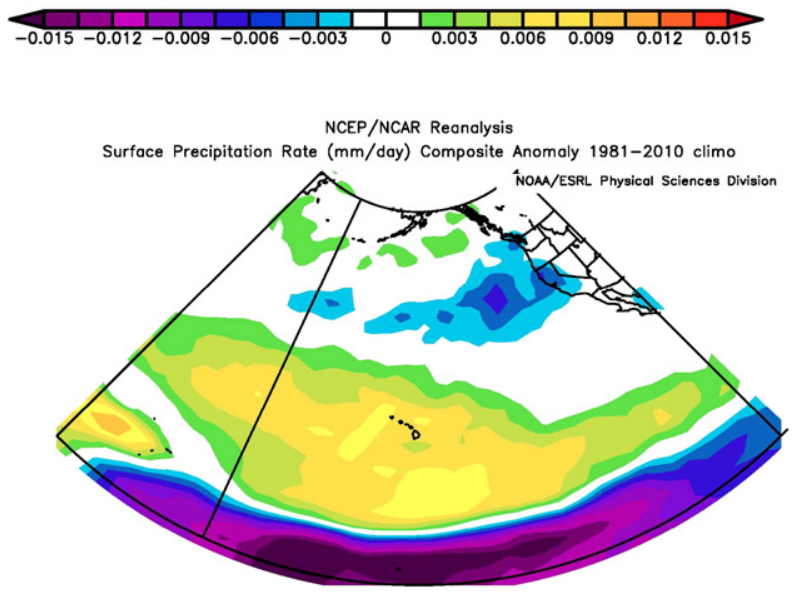

Nov to Apr: $1973,1978,1981,1983,1984,1992,1995,1998,2003,2007$

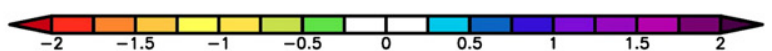

Fig. 2. Circulation anomaly features of representative dry "winter" seasons. Top panel: Anomalous near-surface $(1000 \mathrm{mb})$ vector wind field $(\mathrm{m} / \mathrm{s})$ for the period November-April of the years listed in Table 3 (year refers to that of January). Middle panel: Anomalous vertical velocity at $700 \mathrm{mb}$ (Pa/s, positive downward). Bottom panel: Anomalous rain rate $(\mathrm{mm} / \mathrm{d})$. Data from NCEP Reanalysis; 1981-2010 climatology.

Fig. 3. Anomalous anticyclonic circulation is centered near and to the northwest of the Islands and is associated with strongly divergent flow to the south and strong anomalous subsidence over Hawai'i. Both sets of seasonal droughts are accompanied by enhanced rainfall 


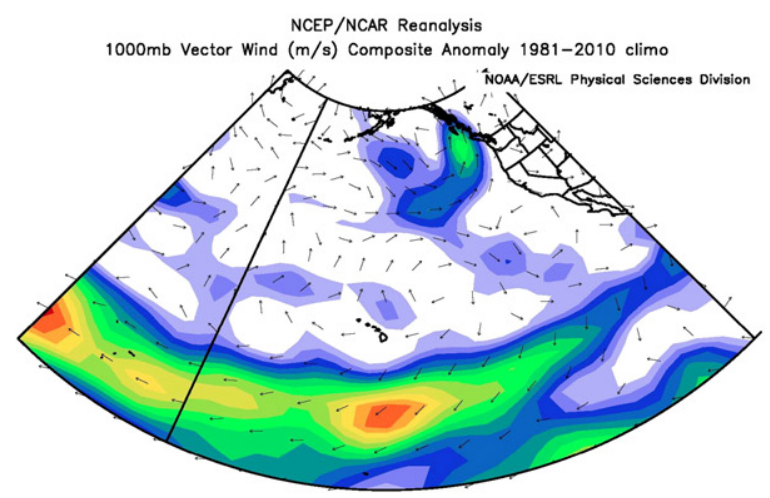

May to Oct: $1949,1953,1971,1973,1975,1976,1984,1999,2003,2007$
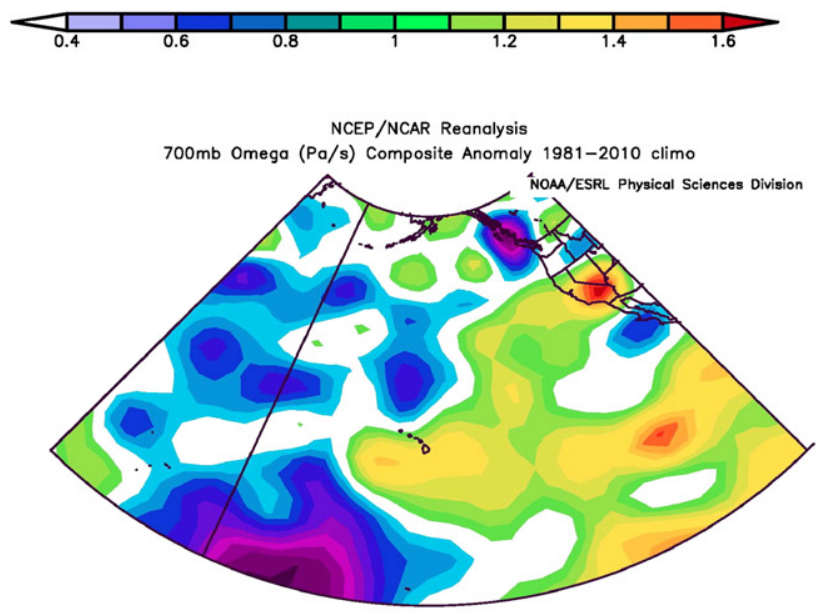

May to Oct: $1949,1953,1971,1973,1975,1976,1984,1999,2003,2007$
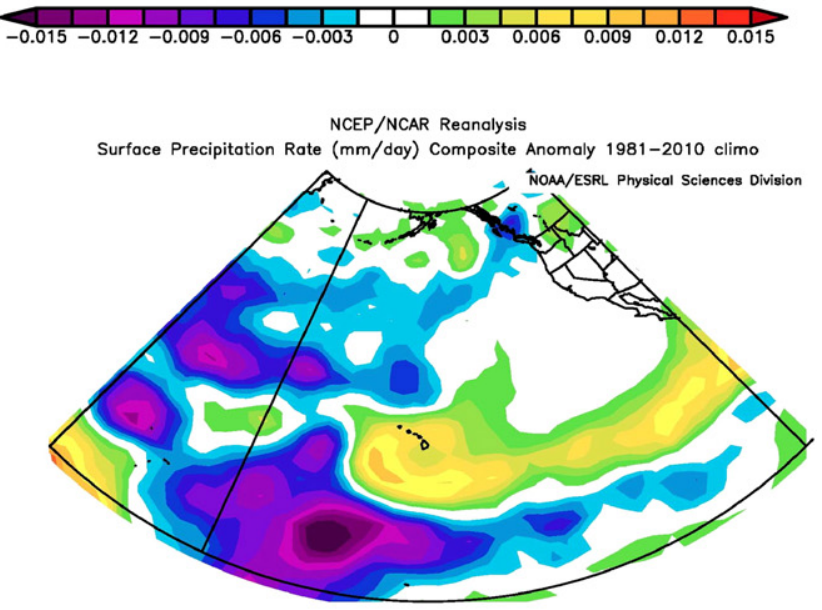

May to Oct: $1949,1953,1971,1973,1975,1976,1984,1999,2003,2007$

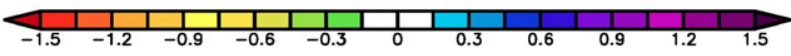

Fig. 3. Same as Fig. 2, but for years with summer (May-October) drought for the years listed in Table 3.

in the region of the Intertropical Convergence Zone (ITCZ) to the south with drying to the north, including the Hawaiian Islands. There is no clear association between dry summers and either the warm or cool ENSO phase. The large-scale anomalous rainfall pattern, shown in Fig. 3, points to an interesting distinction in the location of the rainfall deficit between the winter and summer time regimes.
For the former, the anomalous dryness is located more directly over and south of Hawai'i, whereas for the latter season, the strongest dryness is over the Islands and extending eastwards toward North America.

Table 4 lists the corresponding 10 wettest November-April and May-October seasons. Analogous to Figs. 2 and 3 for the driest seasons, Figs. 4 and 5 illustrate the composite circulation patterns for the corresponding set of the 10 wettest six-month seasons. In contrast to the driest years, the wettest winters tend to correspond to La Niña conditions. In common with the dry years, the mean relative anomaly for each 10 -year set is in the range of $\sim 40-50 \%$ of the long-term mean. The winter anomaly patterns shown in Fig. 4 depict low-level convergence around the Islands, and strong rising motion with above-average rainfall rates. Comparison with Fig. 2 in particular shows a distinctive reversal in the anomalous circulation in the North Pacific with a weaker Aleutian cyclone during this wet winters. Wet summers show generally stronger Northeast Trades and enhanced rainfall over and to the north of the ITCZ.

Wet summers (Table 4 and Fig. 5) appear to be associated with more localized anomalous circulation features, such as anomalous near-surface cyclonic flow around the Islands and anomalous northward flow from the region of the ITCZ. The anomalous rising motion is of smaller spatial scale compared to the other seasonal extremes, which is reflected in the localized nature of the heavier than normal rainfall. It is interesting that many of these years are associated with transitions to/from El Niño or La Niña years or ENSO-neutral years (K. Kodama, National Weather Service, Honolulu, 2011, personal communication).

\subsection{Low frequency variability}

\subsubsection{Decadal-scale patterns}

The Hawaiian Islands have also experienced anomalous rainfall on decadal and multidecadal time scales, with a tendency for lower precipitation in recent decades (Chu et al., 2010). For extended dry and wet periods starting before 1948, we composited data from the HRA in order to examine possible secular changes in the large-scale atmospheric circulation over the North Pacific. In Table 5 we list the decades with the largest dry and wet percent departures from the long-term seasonal means. As was done previously, we show the anomaly fields for $1000 \mathrm{mb}$ vector wind, $700 \mathrm{mb}$ vertical motion and surface rainfall rate for November-April composited for the most extreme consecutive dry 10-year periods covering the interval since 1948 (based on the NRA data set) and prior to 1948 based on the HRA data set (Figs. 6, 7). A similar analysis was done for the May-October season (Figs. 8, 9).

Table 4

As in Table 3 but for the 10 wettest November-April and May-October seasons.

\begin{tabular}{lllll}
\hline November-April rainfall & & & \multicolumn{2}{l}{ May-October rainfall } \\
\cline { 5 - 5 } Year & \% of Normal & & Year & \% of Normal \\
\hline $1981-1982$ & $163.2 \%$ & & 1982 & $157.1 \%$ \\
$1968-1969$ & 161.4 & & 1989 & 147.2 \\
$1988-1989^{\Delta \Delta}$ & 153.2 & 1958 & 139.9 \\
$1978-1979$ & 153.0 & 1994 & 131.5 \\
$1979-1980^{\text {a }}$ & 151.3 & 1956 & 127.4 \\
$1967-1968^{\Delta}$ & 149.5 & 1978 & 127.0 \\
$1970-1971^{\Delta}$ & 143.8 & 1997 & 126.7 \\
$1990-1991$ & 142.5 & 1967 & 124.1 \\
$2003-2004$ & 138.9 & 1992 & 120.2 \\
$1950-1951^{\Delta}$ & 138.6 & 1987 & 119.3
\end{tabular}

Moderate La Niña events are denoted by a ${ }^{\Delta}$, strong La Niña events are denoted by ${ }^{\Delta \Delta}$ For the May-October season the ENSO years are for $($ Year +1$)$ of the event.

a Weak La Niña year. 


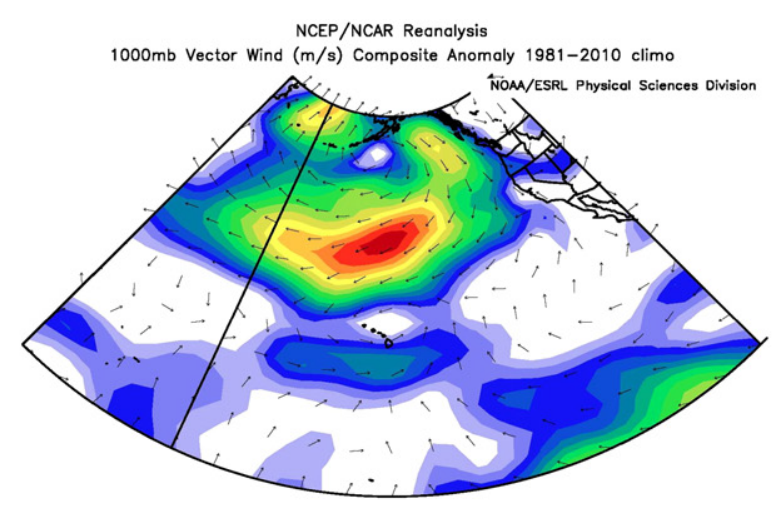

Nov to Apr: $1951,1969,1989,1979,1968,1971,1980,1982,1991,2004$

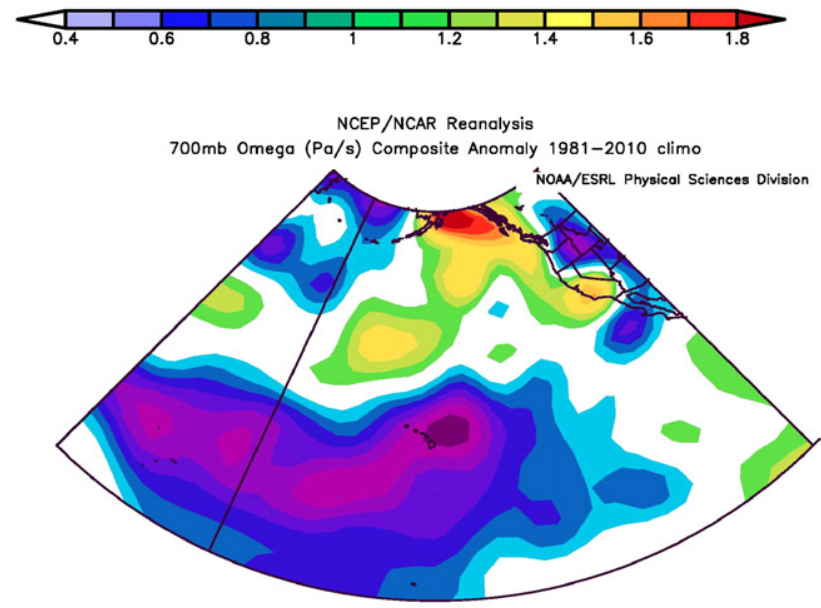

Nov to Apr: $1951,1969,1989,1979,1968,1971,1980,1982,1991,2004$

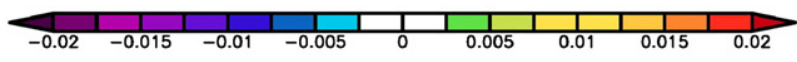

NCEP/NCAR Reanolysis

Surfoce Precipitation Rate (mm/day) Composite Anomaly 1981-2010 climo

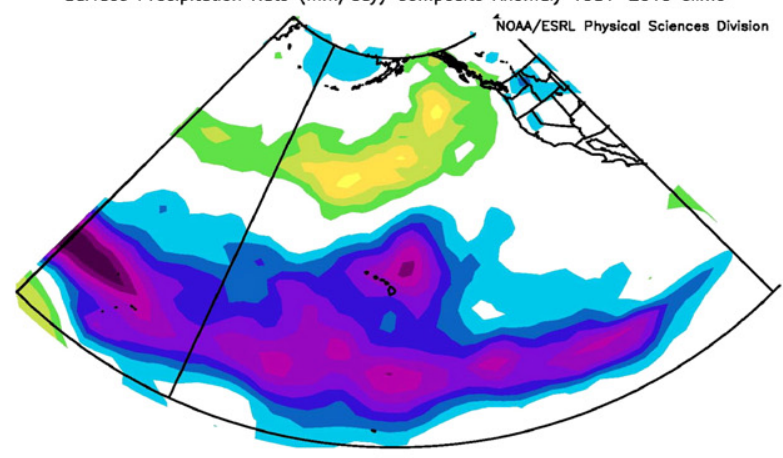

Nov to Apr: $1951,1969,1989,1979,1968,1971,1980,1982,1991,2004$

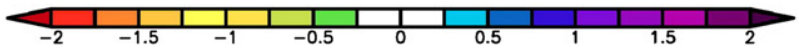

Fig. 4. Same as Fig. 2 but for the 10 wettest November-April years listed in Table 4.

The anomalous circulation patterns associated with the decadal-scale extremes are similar to those based on averaging the set of individual dry years (Table 3). As it turned out, the nominally dry November-April 10-year stretch from 1924-1925 through 1933-1934 was largely the result of the extremely dry winter of 1925-1926, which coincided with a strong El Niño event (Kiladis and Diaz, 1989)-In fact this is the driest winter on record for Hawai'i with only $42 \%$ of average rainfall. We chose

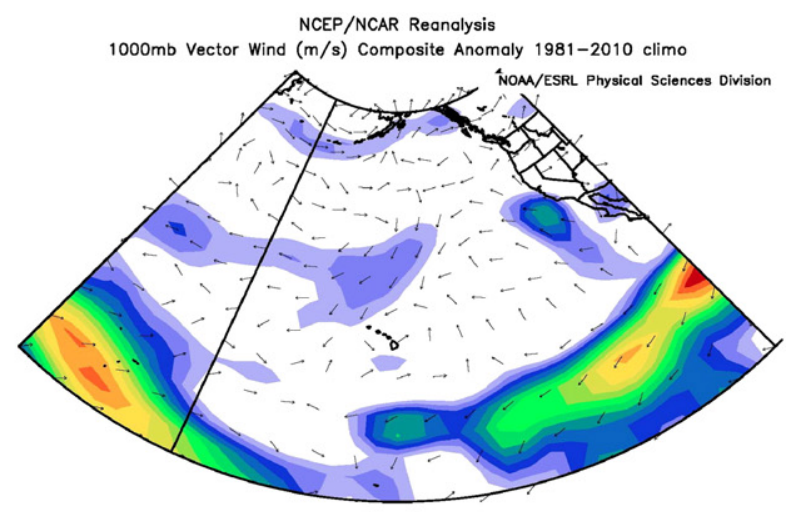

May to Oct: $1958,1956,1967,1978,1982,1987,1992,1994,1997,1989$

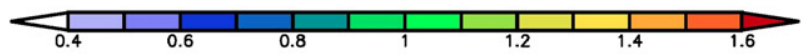

NCEP/NCAR Reanalysis

$700 \mathrm{mb}$ Omega $(\mathrm{Pa} / \mathrm{s})$ Composite Anomaly 1981-2010 climo

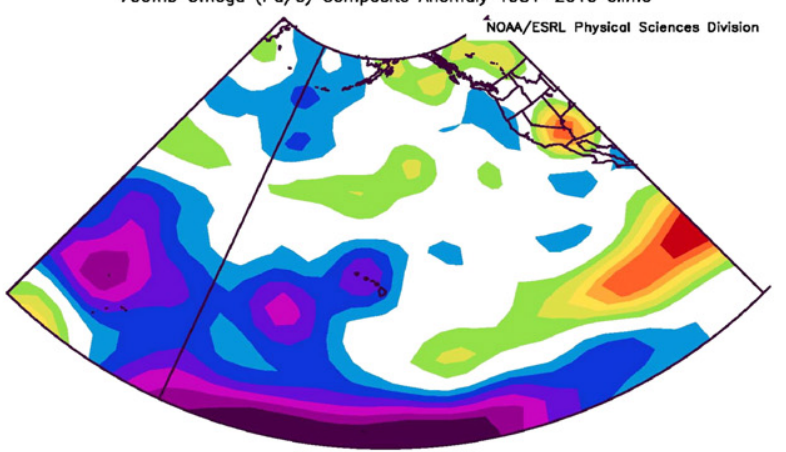

May to Oct: $1958,1956,1967,1978,1982,1987,1992,1994,1997,1989$

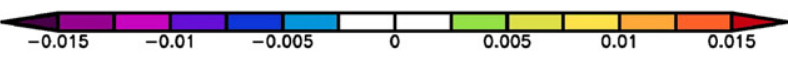

NCEP/NCAR Reanalysis

Surface Precipitation Rate (mm/day) Composite Anomaly 1981-2010 climo

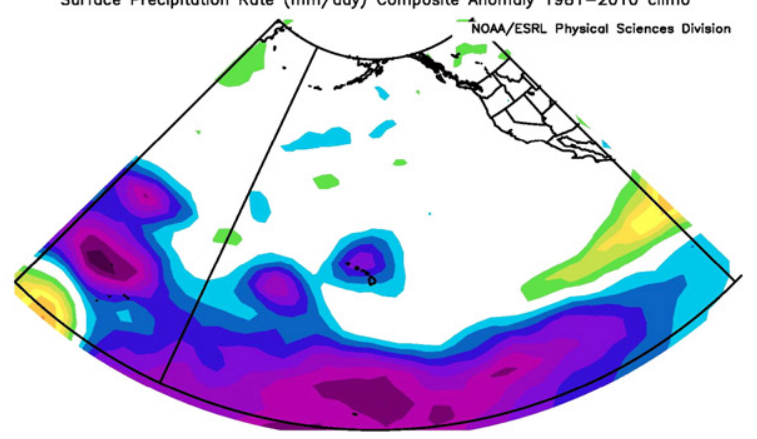

Moy to Oct: $1958,1956,1967,1978,1982,1987,1992,1994,1997,1989$

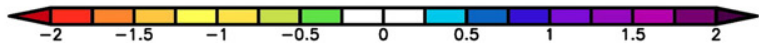

Fig. 5. Same as Fig. 4, but for the wettest summer seasons listed in Table 4.

to reproduce the corresponding pattern for this one season for reference, as one-half of the seasons in this 10 -year composite had normal to above-normal rainfall.

The spatial scale and magnitude of the anomalies for the annual versus decadal composite averages for the May-October season tends to be somewhat weaker compared to that for the November-April season (e.g., compare Figs. 2 and 3 with Figs. 6 and 9; and Figs. 4 and 5 with Figs. 8 and 10). In general during dry winter seasons, anomalous 
Table 5

Listing of significant wet and dry season decadal and multidecadal dry and wet periods expressed as percentages relative to the 1920-2007 means. Data considered for the full period of record to examine patterns in the recent (post 1950) and earlier record.

\begin{tabular}{|c|c|c|c|}
\hline \multicolumn{4}{|c|}{ Decadal scale (driest/wettest 10 consecutive years) } \\
\hline \multicolumn{2}{|l|}{ November-April } & \multicolumn{2}{|l|}{ May-October } \\
\hline Years & $\%$ of Normal & Years & $\%$ of Normal \\
\hline Deficient rainfall & & Deficient rainfall & \\
\hline $1991-1992$ to $2000-2001$ & $80.6 \%$ & $1968-1977$ & $80.2 \%$ \\
\hline $1924-1925$ to $1933-1934$ & $89.8 \%$ & $1944-1953$ & $87.3 \%$ \\
\hline Abundant rainfall & & Abundant rainfall & \\
\hline $1966-1967$ to $1975-1976$ & $117.9 \%$ & 1934-1943 & $122.3 \%$ \\
\hline $1946-1947$ to $1955-1956$ & $109.2 \%$ & 1985-1994 & $114.9 \%$ \\
\hline \multicolumn{4}{|c|}{ Multidecadal scale (driest/wettest 25 years) } \\
\hline \multicolumn{2}{|l|}{ November-April } & \multicolumn{2}{|l|}{ May-October } \\
\hline Years & $\%$ of Normal & Years & $\%$ of Normal \\
\hline Dry $1982-1983$ to $2006-2007$ & $91.0 \%$ & 1953-1977 & $93.4 \%$ \\
\hline Wet $1947-1948$ to $1971-1972$ & $107.6 \%$ & 1924-1948 & $107.0 \%$ \\
\hline
\end{tabular}

anticylonic flow is present in the vicinity of Islands with divergent flowpoleward to the north and equatorward to the south. Anomalous subsidence is then found across a broad belt of the subtropical North Pacific, with drier than normal conditions present in the general region near Hawai'i. A stronger (weaker) than normal Aleutian Low accompanies the above pattern for drier (wetter) winters. For drier summers stronger northeast trades are evident to the south of the Islands, and these converging winds enhance rainfall southwest of the Islands. Enhanced subsidence and drier conditions are then more prevalent over the Islands. The zonally extensive anomalous vertical motion field for the longer time scale (Figs. 6, 8, 9 and 10) suggests a modulation in the strength of the northern Hadley Cell in our geographic domain (Diaz and Bradley, 2004). During summer drought anomalous low-level divergence is prevalent to the east of the Islands together with a drier ITCZ region to the south and east, with the dryness extending northwest and covering the islands.

\subsubsection{Multidecadal patterns}

Table 5 lists four 25-year intervals-two associated with dry and wet winter seasons and two for the summer season-that were selected to composite the three circulation variables used here to assess differences in drought patterns on different time scales. The maps representing the dry and wet November-April periods (Figs. 11 and 12) depict patterns that are rather similar to those obtained for the shorter averaging intervals (for example compare with Figs. 2, 4, 6, and 8). A robust and prominent feature of winter rainfall variations in Hawai'i is the appreciable change in the North Pacific circulation associated with the Aleutian Low. For the May-October season (Figs. 13 and 14) circulation anomalies that are similar to those at shorter time scales are also evident. In this case changes in the easterly wind regime to the south and east of the Islands is the predominant signal.

\subsubsection{PDO and Hawaiian rainfall}

Times series of statewide and individual island rainfall indicate a substantial modulation of precipitation in Hawai'i related to the PDO (Chu and Chen, 2005). Below we examine whether the nominal negative correlation between precipitation and the PDO index prior to the mid-1970s climate shift may have changed since that time, and if so, suggest some possible causes.

Fig. 15 shows decadally smoothed trends in precipitation for Hawai'i using our serially complete $1920-2007$ precipitation dataset plotted against the similarly smoothed PDO index. Although the record length is insufficient to argue conclusively for a robust association between
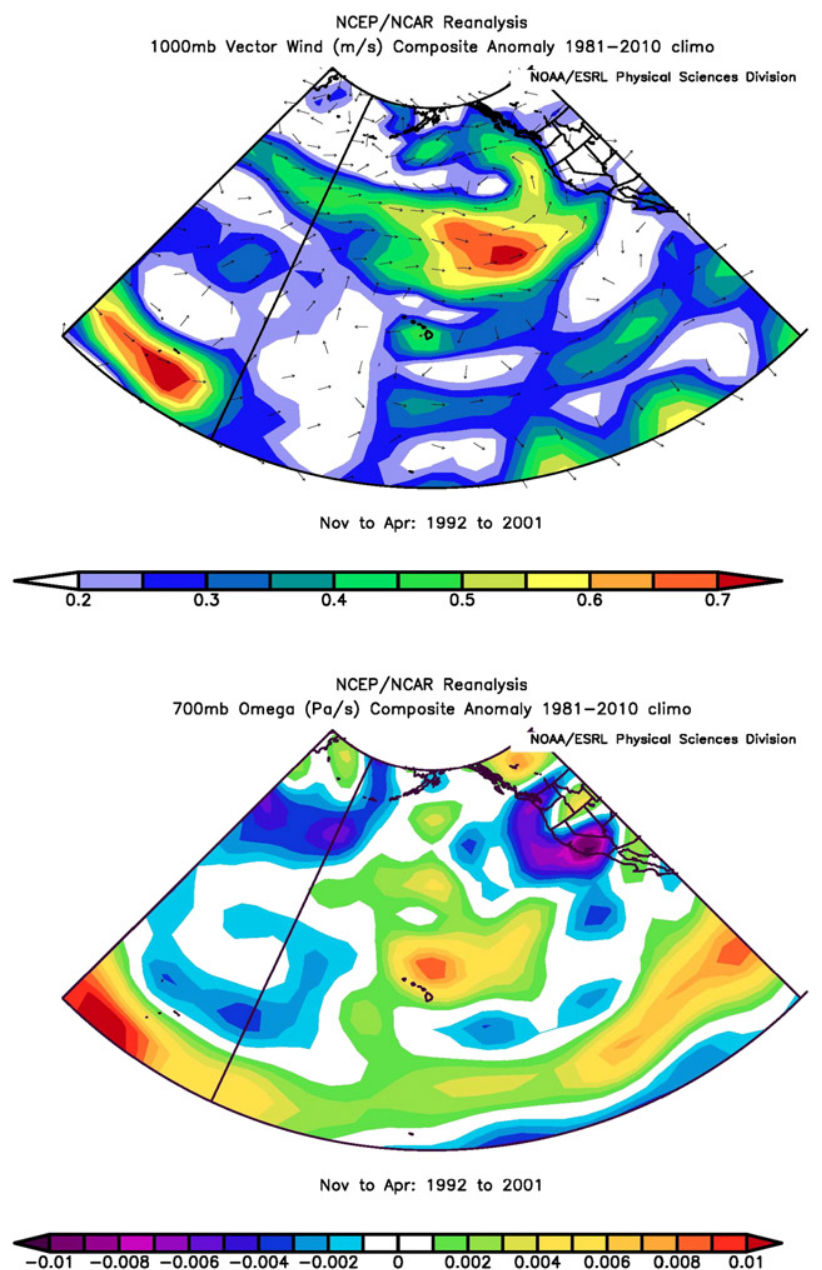

Surface Precipitation Rate (mm/day) Composite Anomaly 1981-2010 climo

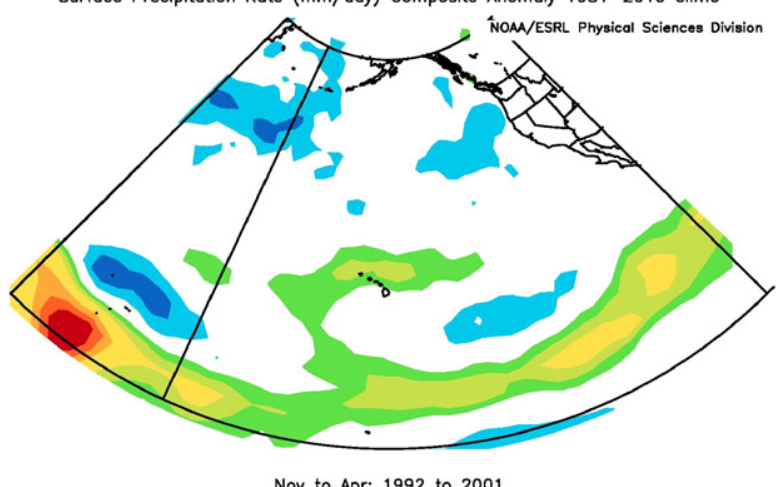

Nov to Apr: 1992 to 2001

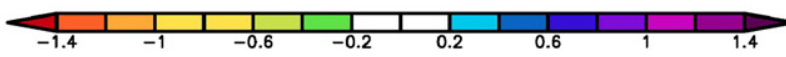

Fig. 6. Same as Fig. 2, except averaged for November-April of 1991-1992 to 20002001.

the PDO and Hawaiian winter rainfall, an analysis of these curves suggest some degree of negative correlation between the series (see Table 6). Certainly for the period prior to the late 1970s climate shift in the Pacific (Graham, 1994; Miller et al., 1997) and in particular for the northernmost island of Kaua'i the correlations are large and statistically significant. However, since about 1980 the rainfall association with the PDO index has become much weaker or non-existent. 
20th Century Reanalysis V2

$1000 \mathrm{mb}$ Vector Wind $(\mathrm{m} / \mathrm{s})$ Composite Anomaly 1981-2010 climo

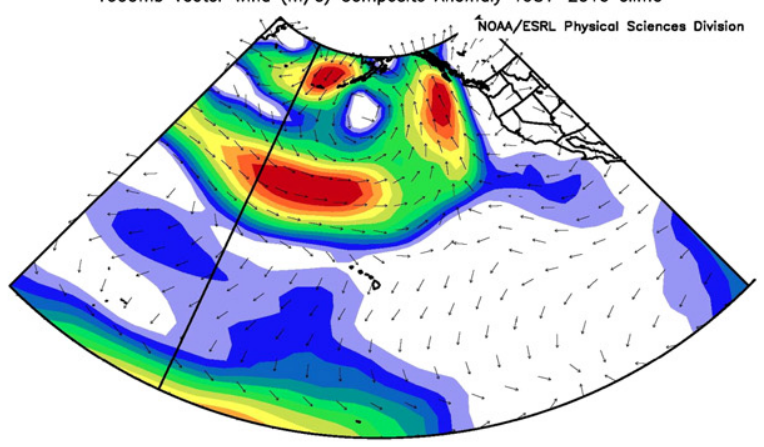

Nov to Apr: 1926
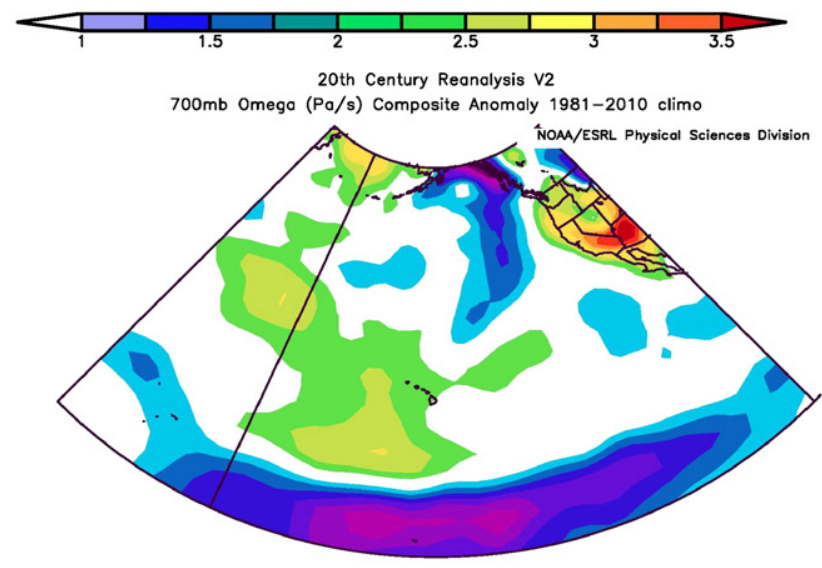

Nov to Apr: 1926
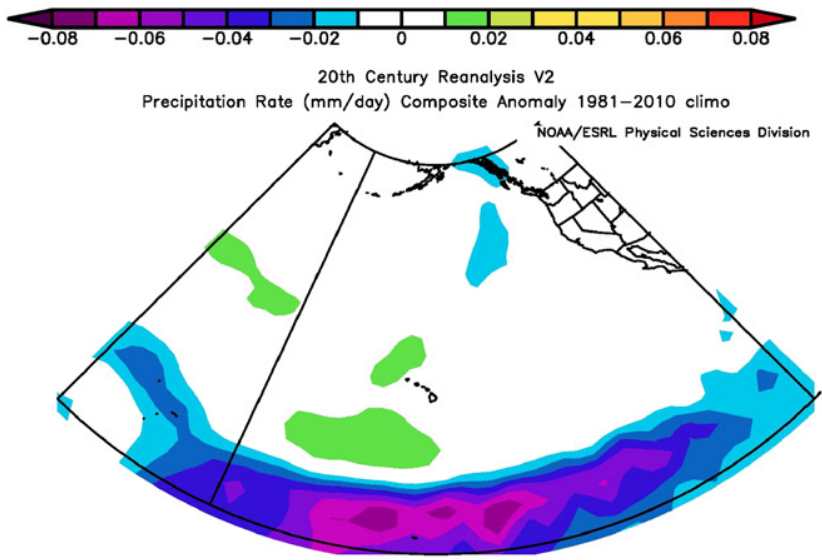

Nov to Apr: 1926

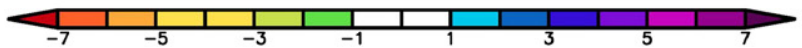

Fig. 7. As in Fig. 2 but for the 1925-1926 winter season.

While the PDO index has been fluctuating near the neutral level since about the mid-1990s, with the seasonal mean PDO index reaching negative territory for 7 of the 13 winters since 1998, rainfall in Hawai'i has remained relatively low. In fact, some of the State's driest years have occurred since the mid-1990s. A recent paper by Li et al. (2011) documents significant heat flux changes in the Pacific and suggests that the changes are closely linked to global warming forcing. In particular, Fig. 5 of Li et al. (2011) suggests lower latent heat fluxes, particularly post-1990 in a broad region around and northeast of Hawai'i, which in the context of the changes illustrated
NCEP/NCAR Reanalysis

$1000 \mathrm{mb}$ Vector Wind (m/s) Composite Anomaly 1981-2010 climo

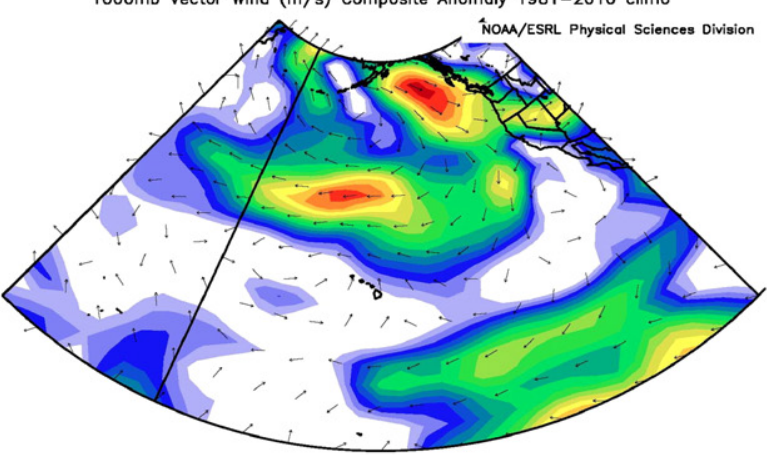

Nov to Apr: 1967 to 1976

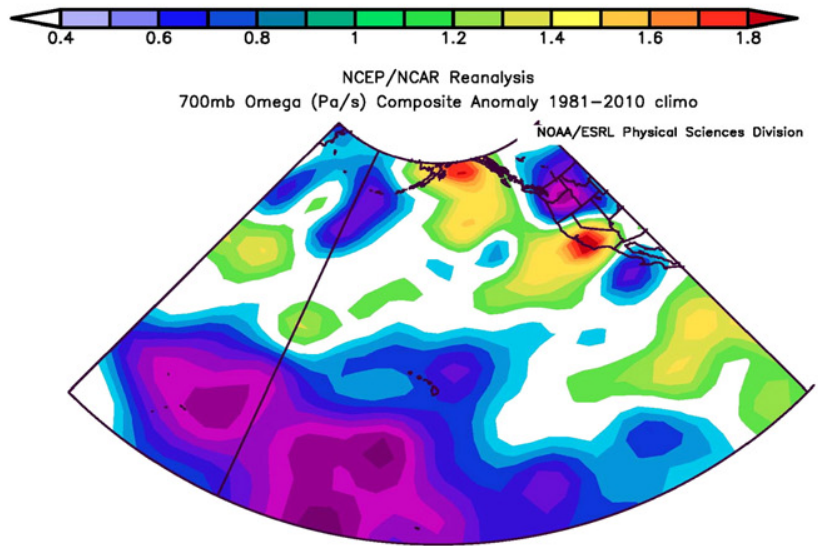

Nov to Apr: 1967 to 1976

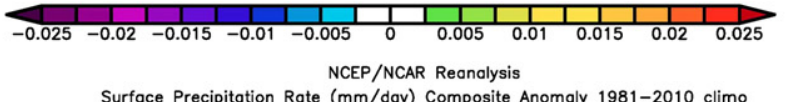

Surface Precipitation Rate (mm/day) Composite Anomaly 1981-2010 climo

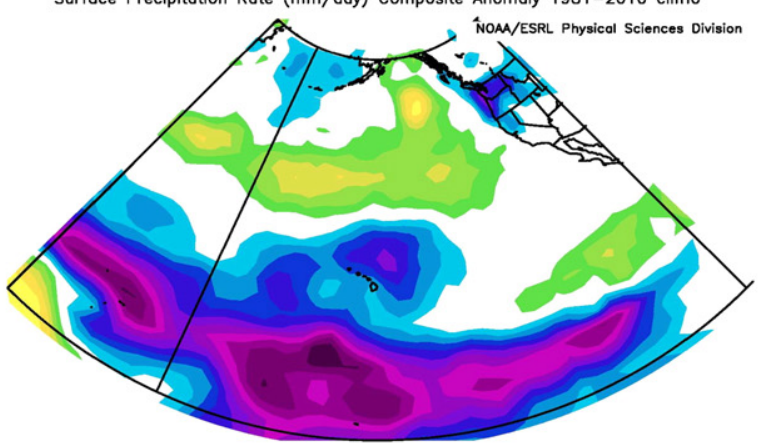

Nov to Apr: 1967 to 1976

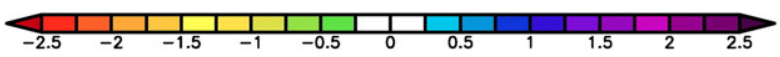

Fig. 8. Same as Fig. 4 except averaged for November-April of 1967-1976.

in, for example Figs. 11 and 13, could have led to reduced rainfall in the Hawaiian Islands in the past couple of decades.

We calculated regressions between pentad (5-year) averages of island and Statewide winter rainfall and similarly averaged values of the November-April PDO Index, shown in Table 6. In general, the coupling between the winter PDO index and winter rainfall is evident during the pre-climate shift period, Maui Nui (including Maui, Lāna'i and Moloka'i) being the exception. The strength of this relationship, as indicated by the slope and $r^{2}$, was lower in the post-shift period in all cases. To illustrate the relative effect of the $\sim 1.5$ PDO units 


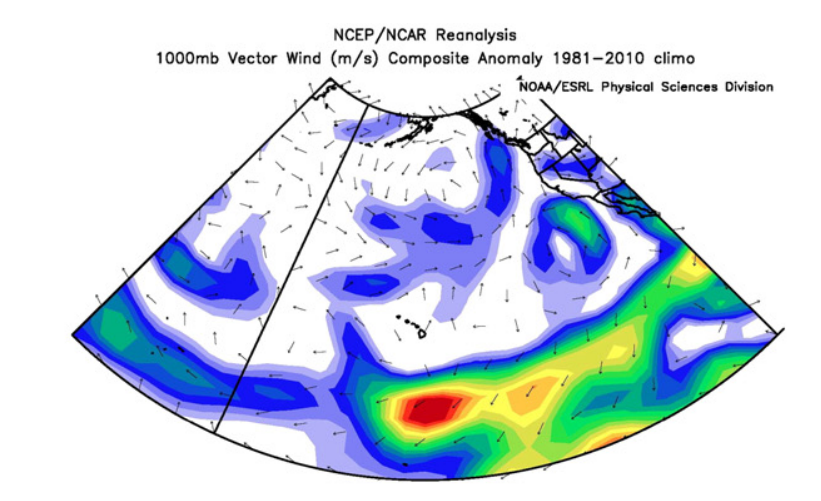

May to Oct: 1968 to 1977

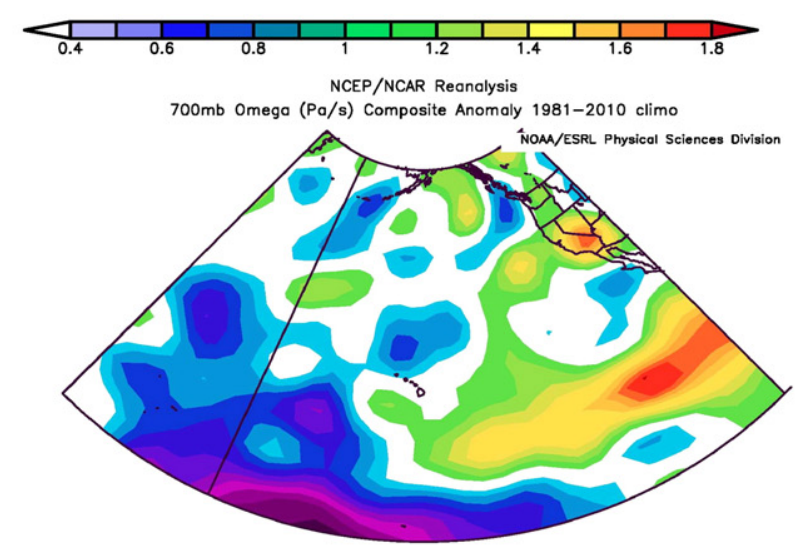

Moy to Oct: 1968 to 1977

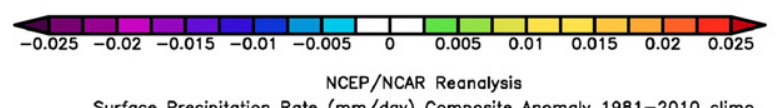

Surface Precipitation Rate (mm/day) Composite Anomaly 1981-2010 climo

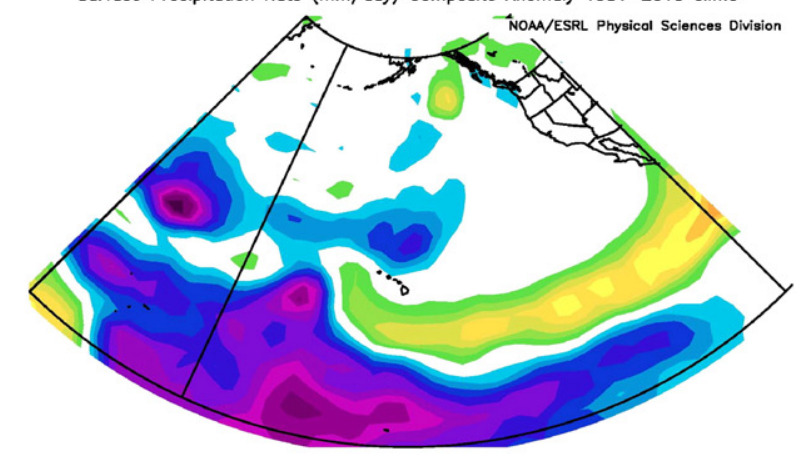

May to Oct: 1968 to 1977

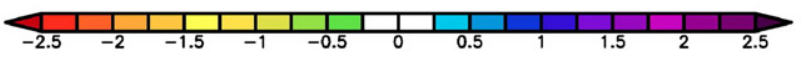

Fig. 9. Same as Fig. 2 except averaged for May-October of 1968-1977.

difference between average high and low phases of the oscillation (based on the relationship prior to the mid-1970s shift), the change in winter precipitation amounts to a variation of about $130 \mathrm{~mm}$ for the State as a whole, or 12\% of its 1920-2007 average of $1064 \mathrm{~mm}$ (Frazier et al., 2011).

In recent decades, winter rainfall in Hawai'i has been lower than would be expected based on the historical relationship with the PDO. Work by Bonfils and Santer (2011) and by Li et al. (2011) suggest the possibility that global warming may influence the temporal characteristics of the PDO mode in the Pacific. Trenberth and Shea (2006) for example have argued for a global warming signal conflated
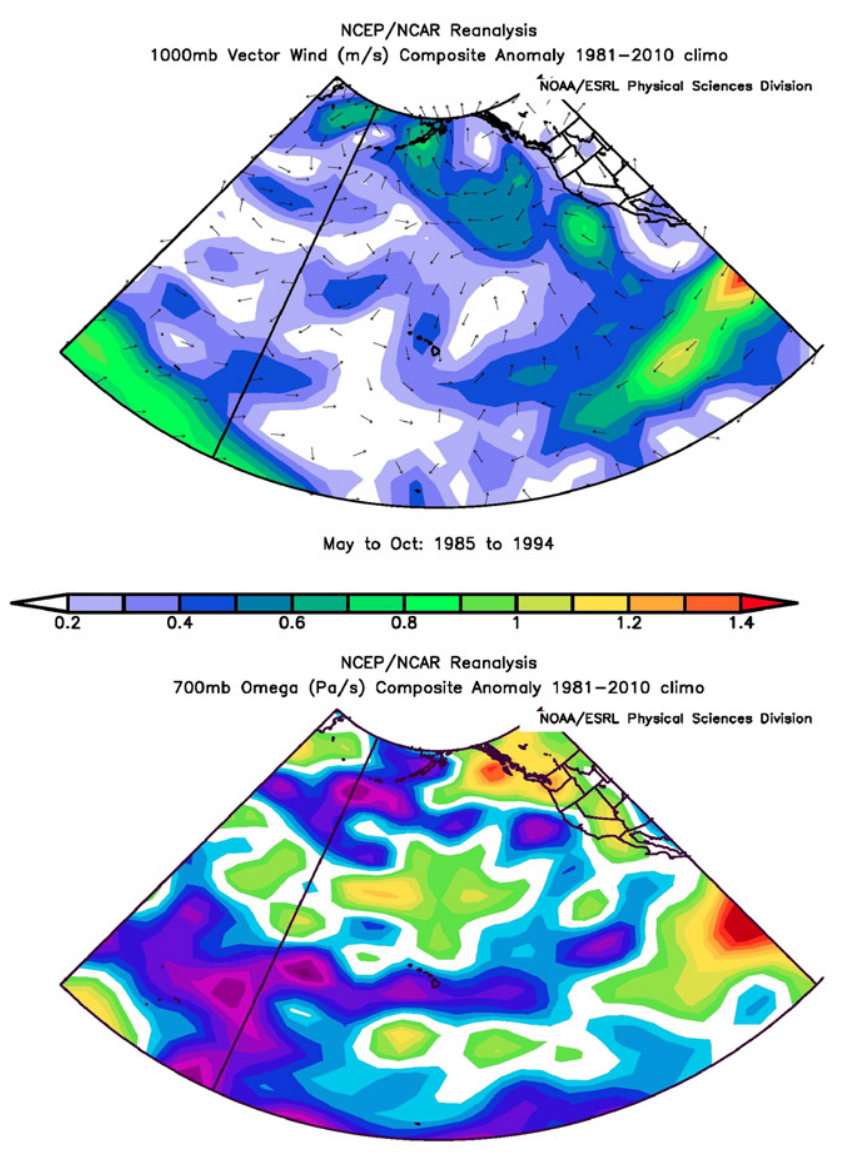

May to Oct: 1985 to 1994

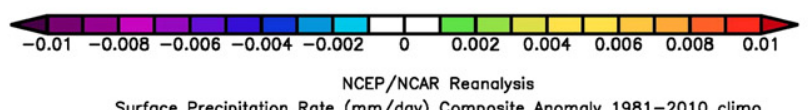

Surface Precipitation Rate (mm/day) Composite Anomaly 1981-2010 climo

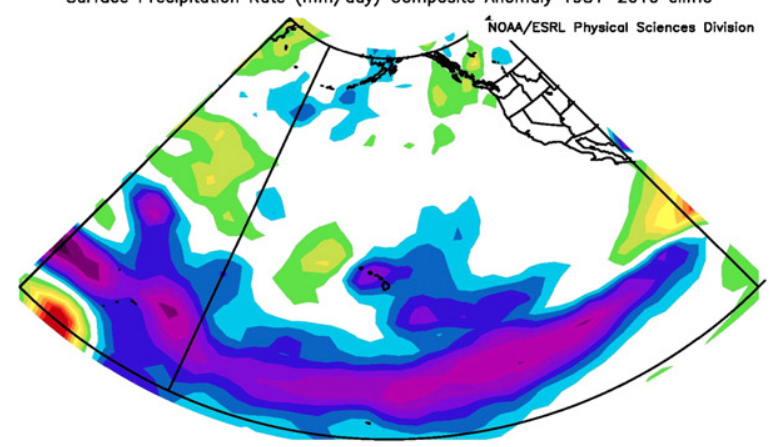

May to Oct: 1985 to 1994

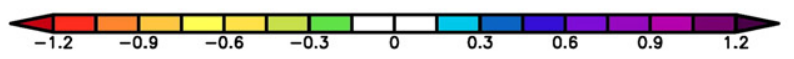

Fig. 10. As in Fig. 5, except for the 10-year period 1985-1994.

with regional sea surface temperature increases associated with the Atlantic Multidecadal Oscillation (AMO), which in turn may have affected the strength of teleconnection patterns. Furthermore, changes due solely to natural (internal) variability that has been documented in a number of studies (e.g., Ramage, 1983; Diaz et al., 2001) are also capable of modulating apparent associations using relatively short periods of record.

The recent change in the strength of the association of the PDO mode with winter rainfall in Hawai'i may be a natural fluctuation, and the climate record is too short to conclude with any confidence 


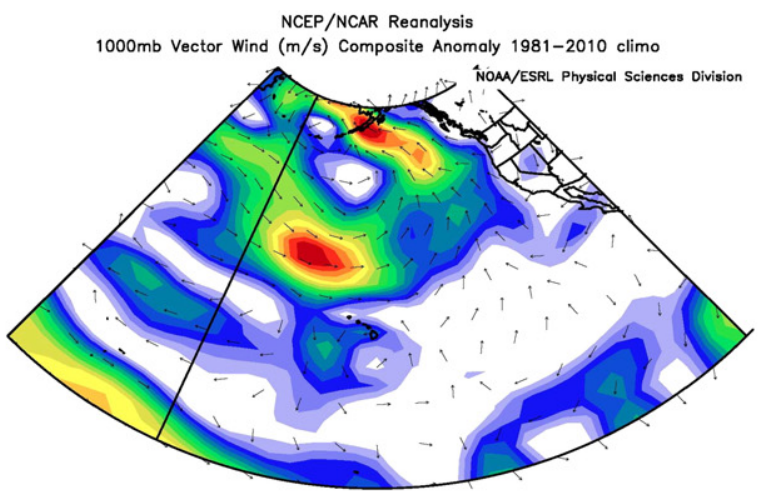

Nov to Apr: 1983 to 2007

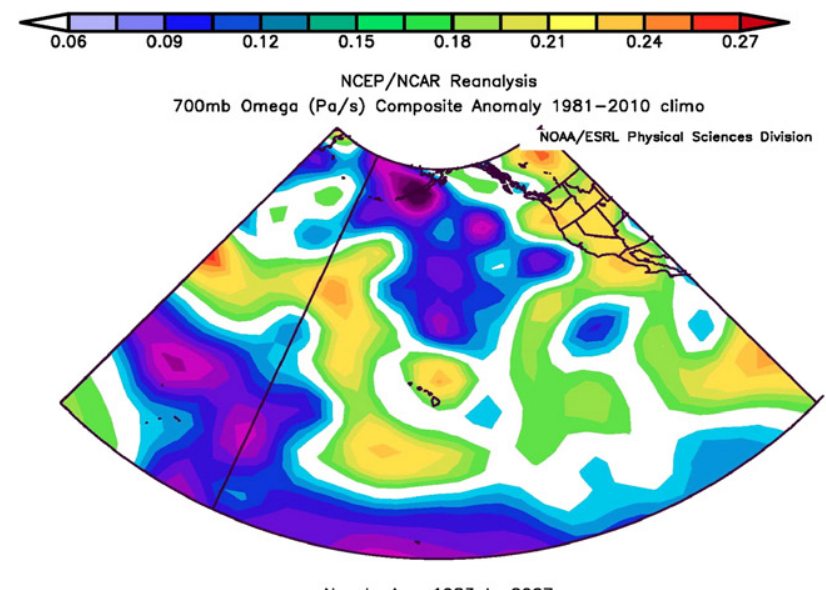

Nov to Apr: 1983 to 2007

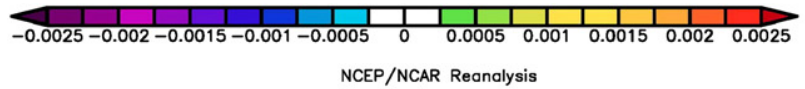

Surfoce Precipitation Rate (mm/day) Composite Anomaly 1981-2010 climo

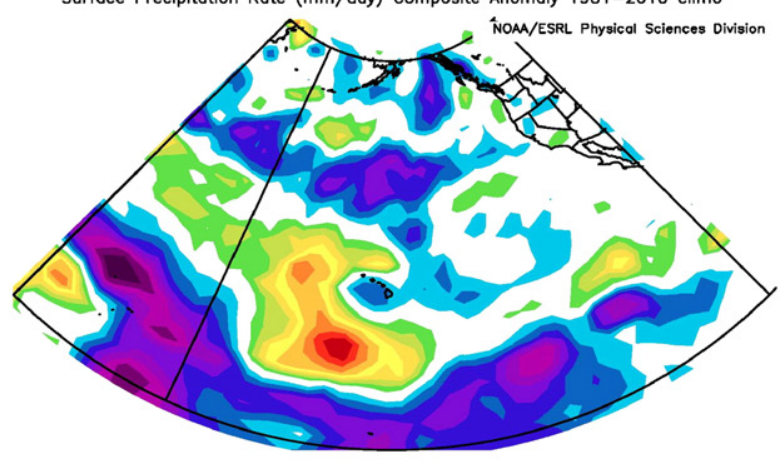

Nov to Apr: 1983 to 2007

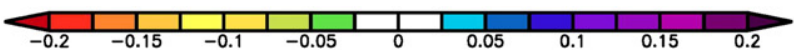

Fig. 11. Same as Fig. 2 except for the 25-year period 1983-2007.

that such changes are in fact taking place. However, it is at least plausible that the apparent change in the PDO-Hawai'i rainfall association of the past decade or two will prove to be robust (see Grassi et al., 2012).

\section{Summary and discussion}

We examined the question of whether the anomalous circulation patterns associated with dry episodes in the Hawaiian Islands are different depending on the time scale in question. At the shorter seasonal

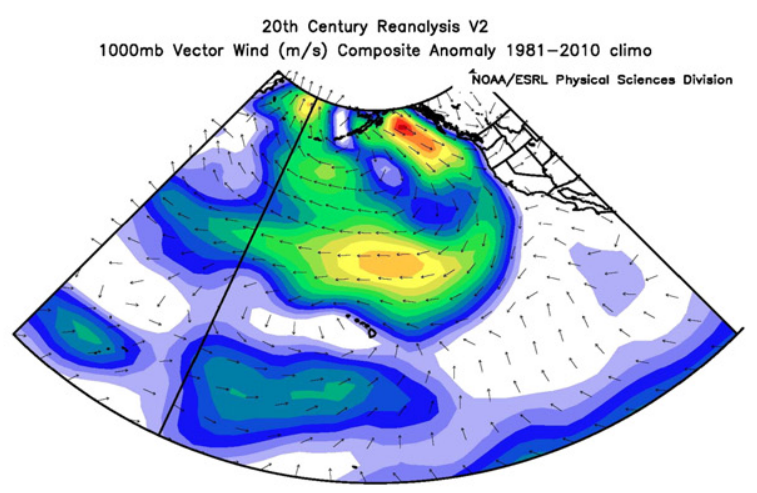

Nov to Apr: 1948 to 1972
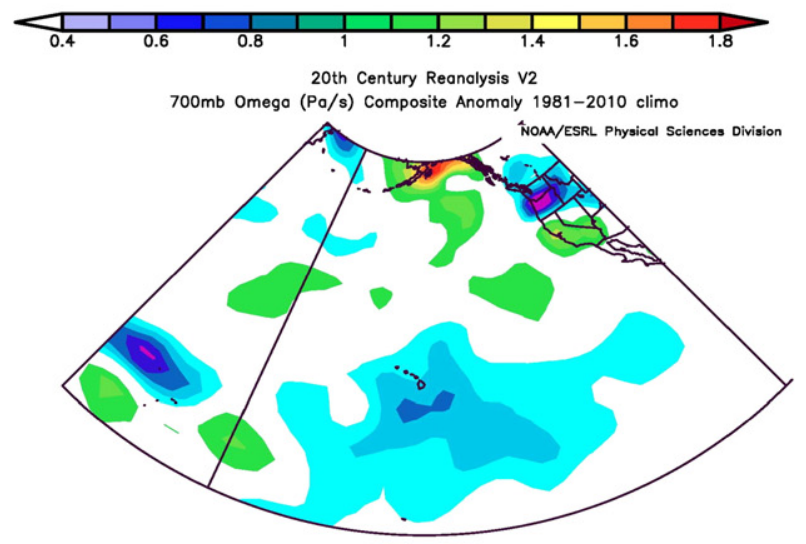

Nov to Apr: 1948 to 1972
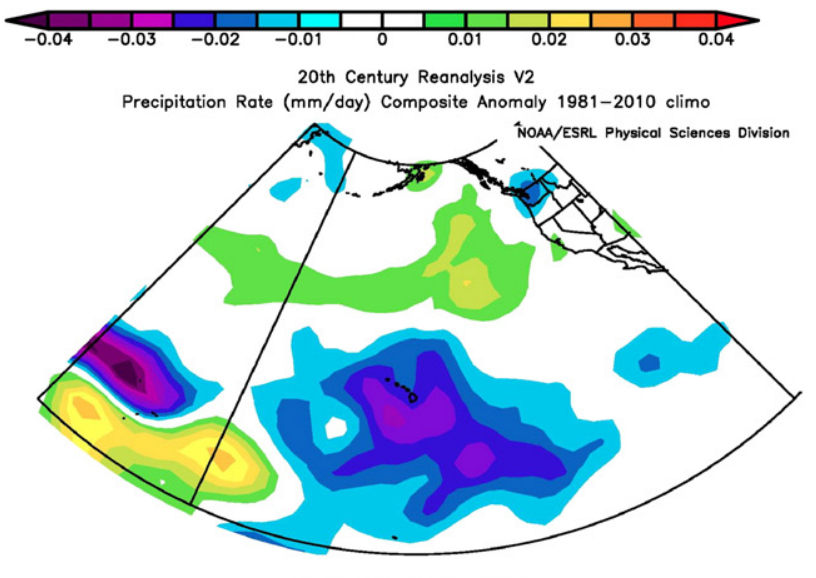

Nov to Apr: 1948 to 1972

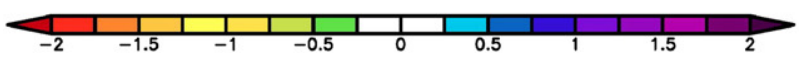

Fig. 12. Same as Fig. 4 except for the 25-year period 1948-1972.

time scale, the circulation pattern affecting the islands during winter dry spells exhibit the nominal characteristics present during strong or moderate El Niño events-in fact many of the driest winter seasons are El Niño years. Those years often display anomalous cyclonic flow to the north and anticyclonic flow to the south with strong sinking motion straddling the latitude of the islands. For longer averaging periods (10-25 years), the spatial scale of the anomalies widen somewhat, but the composite anomalous circulation fields contains elements present at all time scales. There is a suggestion of a weakening of the northeast trade winds since the mid-1970s (Garza et al., 2012), and a number of studies that suggest changes in the width of the tropical 


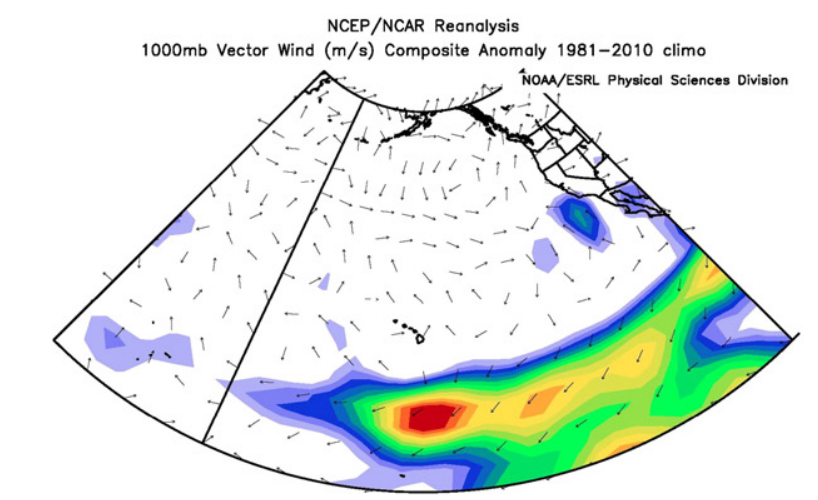

May to Oct: 1953 to 1977

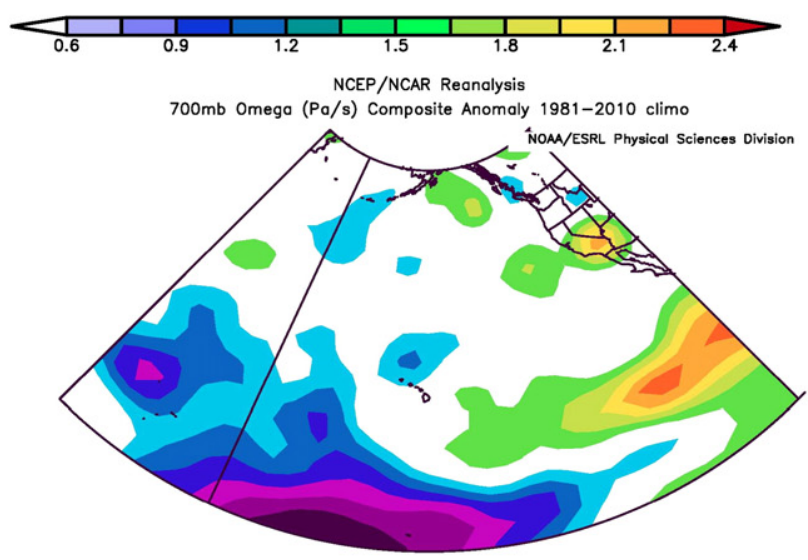

May to Oct: 1953 to 1977
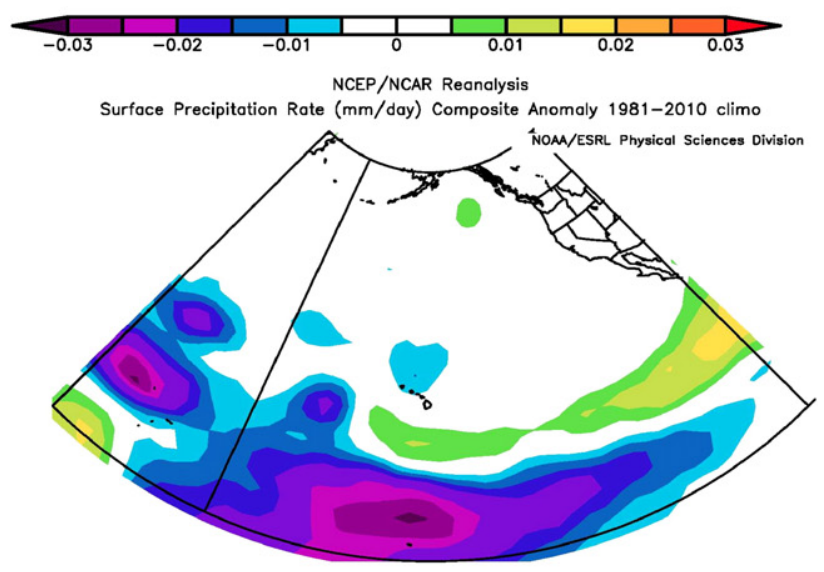

Moy to Oct: 1953 to 1977

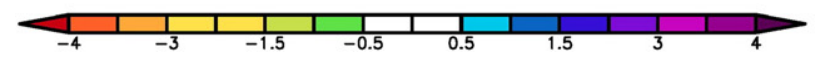

Fig. 13. As in Fig. 3, except for the 25-year period 1953-1977.

belt (Seidel et al., 2008; Lu et al., 2007, 2009), both of which would affect the Hawaiian Islands with diminished precipitation.

Previous work by Timm and Diaz (2009) using synoptic-statistical methods to downscale IPCC AR4 (Solomon et al., 2007) climate model projections for the latter part of the 21st century found a possible 5$10 \%$ decrease in winter rainfall for the State. In a separate study using ENSO and PNA variations from observations and from the IPCC climate models to project precipitation changes in Hawai'i, (Elison Timm et al., 2011, their Fig. 7) showed that heavy rainfall (daily rainfall totals

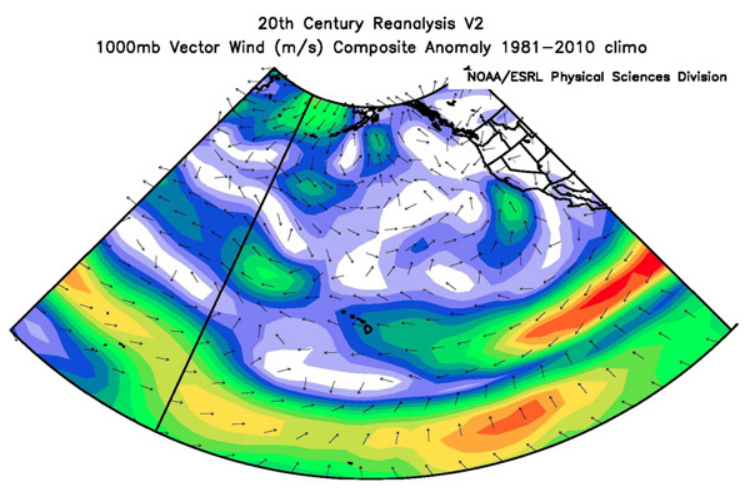

Moy to Oct: 1924 to 1948
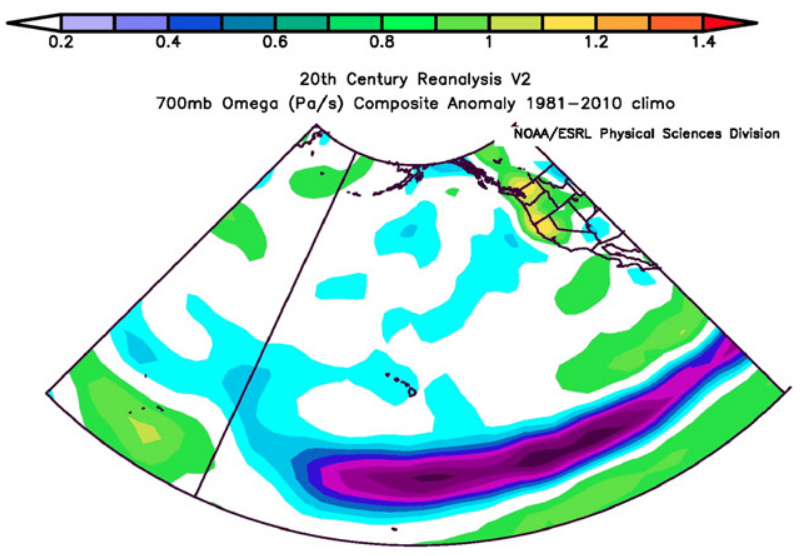

Moy to Oct: 1924 to 1948
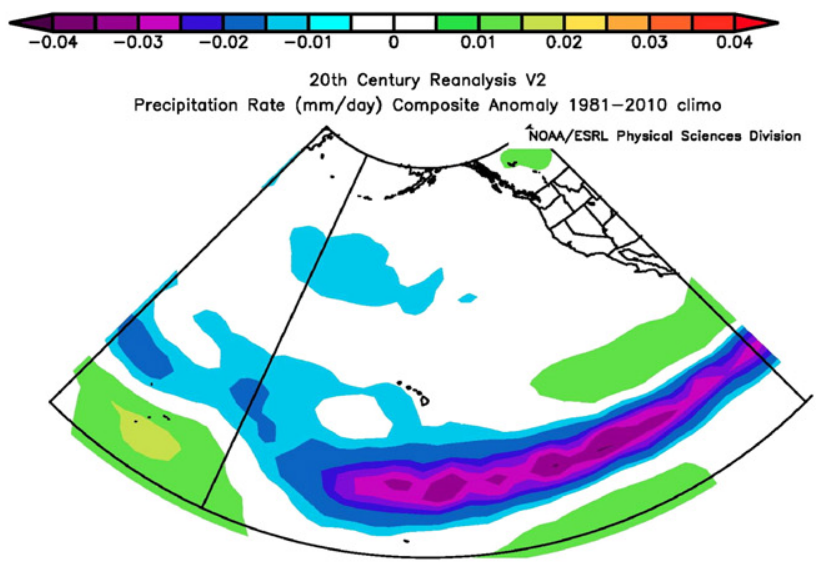

May to Oct: 1924 to 1948

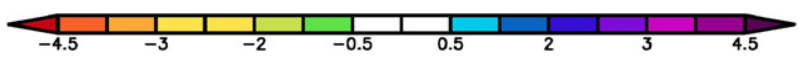

Fig. 14. Same as Fig. 5 except for the 25-year period 1924-1948.

exceeding the 90th percentile), declined significantly following the mid-1970s climate shift, and was projected to remain lower and possibly decrease further.

Provisional rainfall data since 2007 available from NCDC show continuing dryness throughout the State of Hawai'i affecting both winter and summer seasons, with severe to extreme drought covering nearly the entire State in 2010 (http://droughtmonitor.unl.edu). In 2012 drought conditions are once again expanding over the Islands, with severe to extreme drought covering much of the leeward areas of the State. 


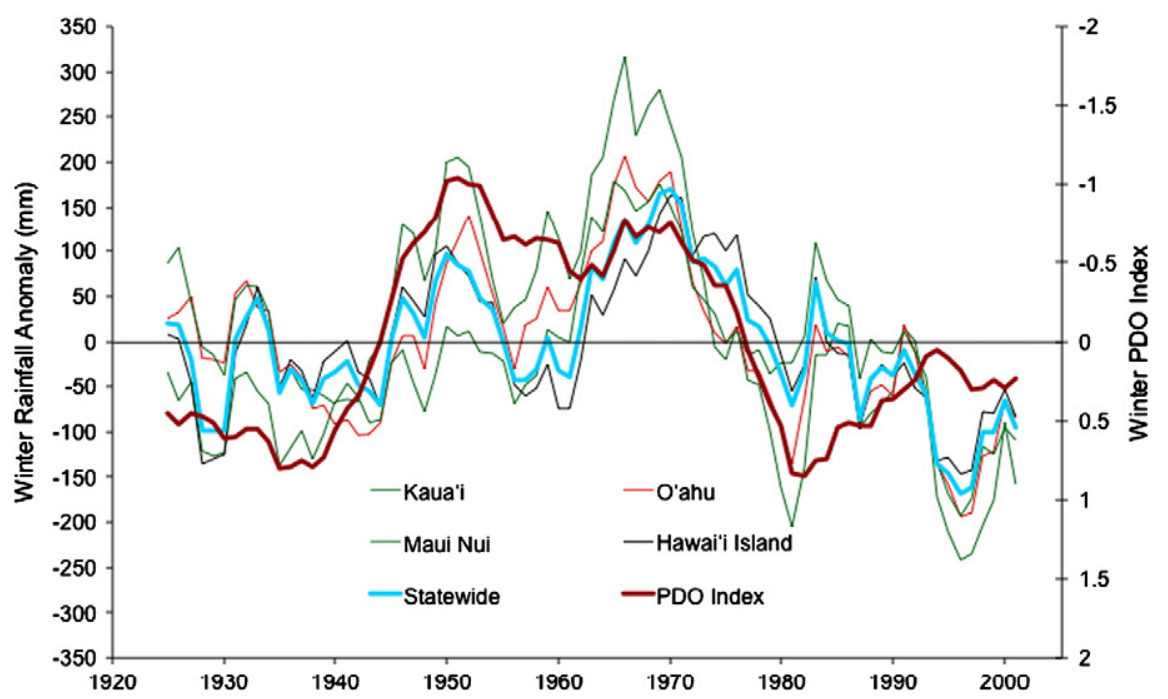

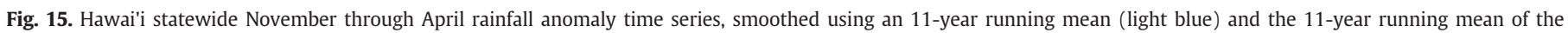

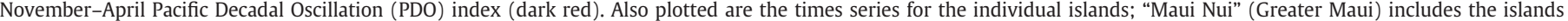
of Maui, Moloka'i, and Lāna'i. Note that the PDO index scale (right axis) is reversed.

\section{Acknowledgments}

This work was partially supported by a grant from the National Oceanic and Atmospheric Administration's (NOAA) Climate Program Office under its Climate Change and Data Detection program (award number NA09OAR4310103), and by a grant from the Pacific Island Climate Change Cooperative (PICCC; award number 12200-A-J027). We are especially grateful to Abby Frazier for her assistance in developing the rainfall data set. We also thank the reviewers for their constructive suggestions.

\section{References}

Bonfils, C., Santer, B.D., 2011. Investigating the possibility of a human component in various Pacific decadal oscillation indices. Climate Change 37, 1457-1468.

Cao, G., Giambelluca, T.W., Stevens, D.E., Schroeder, T.A., 2007. Inversion variability in the Hawaiian trade wind regime. Journal of Climate 20, 1145-1160.

Chu, P.-S., Nash, A.J., Porter, F.-Y., 1993. Diagnostic studies of two contrasting rainfall episodes in Hawaii: Dry 1981 and Wet 1982. Journal of Climate 6, 1457-1462.

Chu, P.-S., 1989. Hawaiian drought and the Southern Oscillation. International Journal of Climatology 9, 619-631.

Chu, P.-S., Chen, H., 2005. Interannual and interdecadal rainfall variations in the Hawaiian Islands. Journal of Climate 18, 4796-4813.

Chu, P.-S., Chen, Y.R., Schroeder, T.A., 2010. Changes in precipitation extremes in the Hawaiian Islands in a warming climate. Journal of Climate 23, 4881-4900.

Compo, G.P., et al., 2011. The Twentieth Century Reanalysis Project. Quarterly Journal of the Royal Meteorological Society 137, 1-28.

Daly, C., Smith, J., Doggett, M., Malbleib, M., Gibson, W., 2006. High-Resolution Climate Maps for the Pacific Basin Islands, 1971-2000. Oregon State University. Pacific West Regional Office: National Park Service.

Diaz, H.F., Bradley, R.S. (Eds.), 2004. The Hadley Circulation: Present, Past and Future. Kluwer Academic Publishers, Dordrecht (511 pp.).

\section{Table 6}

Linear least-squares regression coefficients of consecutive 5-year averages for individual islands and statewide November-April rainfall versus the corresponding 5-year average PDO Index.

\begin{tabular}{llllll}
\hline & \multicolumn{2}{l}{$\begin{array}{l}\text { Slope } \\
\text { (mm/PDO unit })\end{array}$} & & $r^{2}$ & \\
\cline { 2 - 3 } \cline { 5 - 6 } & $1925-1975$ & $1980-2005$ & & $1925-1975$ & $1980-2005$ \\
\hline Kaua'i & -167 & -120 & & 0.766 & 0.167 \\
O'ahu & -94 & -23 & & 0.355 & 0.008 \\
Maui Nui & -42 & 3 & & 0.112 & 0.000 \\
Hawai'i Island & -85 & -60 & & 0.453 & 0.078 \\
Statewide & -85 & -50 & & 0.502 & 0.054 \\
\hline
\end{tabular}

Diaz, H.F., Hoerling, M.P., Eischeid, J.K., 2001. ENSO variability, teleconnections, and climate change. International Journal of Climatology 21, 1845-1862.

Diaz, H.F., Giambelluca, T.W., Eischeid, J.K., 2011. Changes in the vertical profiles of mean temperature and humidity in the Hawaiian Islands. Global and Planetary Change 77, 21-25.

Eischeid, J.K. Pasteris, P.A. Diaz, H.F, Plantico, M.S. Lott, NJ. 2000. Creating a serially complete, national daily time series of temperature and precipitation for the Western United States. Journal of Applied Meteorology 39, 1580-1591.

Elison Timm, O., Diaz, H.F., Giambelluca, T.W., Takahashi, M., 2011. Projection of changes in the frequency of heavy rain events over Hawai'i based on leading Pacific climate modes. Journal of Geophysical Research 116, D04109. http://dx.doi.org/10.1029/2010JD014923.

Frazier, A.G., 2012. Month-Year Rainfall Maps of the Hawaiian Islands. University of Hawai'i, Department of Geography Master Thesis, 81 pp.

Frazier, A.G., Diaz, H.F., Giambelluca, T.W., 2011. Rainfall in Hawai'i: spatial and temporal changes since 1920. Abstract GC21B-0900 presented at the American Geophysical Union Fall Meeting, San Francisco, December 2011.

Garza, J.A., Chu, P.-S., Norton, C.W., Schroeder, T.A., 2012. Changes in the prevailing trade winds over the islands of Hawai'i and the North Pacific. Journal of Geophysical Research 117, D11109. http://dx.doi.org/10.1029/2011JD016888.

Giambelluca, T.W, Nullet, M.A, Ridgly, M.A. Eyre, P.R., Moncur, JE.T, Price, S, 1991. Drought in Hawai'i. Report R88. Hawai'i Department of Land and Natural Resources, Honolulu (232 pp.).

Giambelluca, T.W., Diaz, H.F., Luke, M.S.A., 2008. Secular temperature changes in Hawai'i. Geophysical Research Letters 35, L12702 http://dx doi.org/10.1029/2008GL034377.

Giambelluca, T.W., Chen, Q., Frazier, A.G., Price, J.P., Chen, Y.-L., Chu, P.-S., Eischeid, J., Delparte, D., 2011. The Rainfall Atlas of Hawai'i . (http://rainfall.geography.Hawai'i.edu).

Giambelluca, TW Chen, Q Frazier, A.G Price, J.P. Chen, Y.-L, Chu, P.-S, Eischeid, J.K. Delparte, D.M., 2012. Online rainfall atlas of Hawai'i. Bulletin of the American Meteorological Society. http://dx.doi.org/10.1175/BAMS-D-11-00228.1.

Graham, N.E., 1994. Decadal-scale climate variability in the tropical and North Pacific during the 1970s and 1980s: observations and model results. Climate Dynamics $10,135-162$.

Grassi, B., Redaelli, G., Canziani, P.O., Visconti, G., 2012. Effects of the PDO phase on the tropical belt width. Journal of Climate 25, 3282-3290.

Kiladis, G.N., Diaz, H.F., 1989. Global climatic anomalies associated with extremes in the Southern Oscillation. Journal of Climate 2, 1069-1090.

Kistler, R., Kalnay, E., Collins, W., Saha, S., White, G., Woollen, J., Chelliah, M., Ebisuzaki, W., Kanamitsu, M. van den Dool, H., Jenne, R., Fiorino, M. 2001. The NCEP/NCAR 50-year Reanalysis: Monthly Means, CD-ROM and Documentation. Bulletin of the American Meteorological Society 82, 152-168.

Li, J., Xie, S.-P., Cook, E.R., Huang, G., D'Arrigo, R., Liu, F., Ma, J., Zheng, X.-T, 2011. Interdecadal modulation of El Niño amplitude during the past millennium. Nature Climate Change 1, 114-118.

Lu, J., Deser, C., Reichler, T., 2009. Cause of the widening of the tropical belt since 1958. Geophysical Research Letters L03803. http://dx.doi.org/10.1029/2008GL036076.

Lu, J., Vecchi, G.A., Reichler, T., 2007. Expansion of the Hadley cell under global warming. Geophysical Research Letters L06805. http://dx.doi.org/10.1029/2006GL028443.

Lyons, S.W., 1982. Empirical orthogonal function analysis of Hawaiian rainfall. Journal of Applied Meteorology 21, 1713-1729.

Miller, A.J., Cayan, D.R., Barnett, T.P., Graham, N.E., 1997. The 1976-77 climate shift in the Pacific. Oceanograpy 7, 21-26.

Ramage, C.S., 1983. Teleconnections and the siege of time. Journal of Climatology 3, 223-231.

Seidel, D.J., Fu, Q., Randel, W.J., Reichler, T.J., 2008. Widening of the tropical belt in a changing climate. Nature Geoscience 1, 21-24. 
Schroeder, T.A., 1993. Climate controls. in Prevailing Trade Winds: Weather and Climate in Hawai'i, pp. 12-36.

Solomon, S., Qin, D., Manning, M., Chen, Z., Marquis, M., Averyt, K.B., Tignor, M., Miller, H.L. (Eds.), 2007. Climate Change 2007: The Physical Science Basis. Contribution of Working Group I to the Fourth Assessment Report of the Intergovernmental Panel on Climate Change. Cambridge University Press, Cambridge and New York.
Timm, O., Diaz, H.F., 2009. Synoptic-statistical approach to regional downscaling of IPCC twenty-first-century climate projections: seasonal rainfall over the Hawaiian Islands. Journal of Climate 22, 4261-4280.

Trenberth, K.E., Shea, D.J., 2006. Atlantic hurricanes and natural variability in 2005. Geophysical Research Letters 33, L12704. http://dx.doi.org/10.1029/2006GL026894. 